\title{
Między langue a parole: język w perspektywie kodowania
}

Słow a kluc z e: langue; parole; perspektywa nadawcy; gramatyka kodowania; semantyka; składnia

Ke y w o r d s: langue; parole; speaker's perspective; encoding grammar; semantics; syntax

\section{Wprowadzenie}

Jak powszechnie wiadomo, rozróżnienie między langue i parole, podobnie jak same terminy, współczesne językoznawstwo zawdzięcza Ferdynandowi de Saussure'owi. Rozróżnienie to w pewnym sensie podzieliło los tezy o znakowym charakterze języka (Danielewiczowa 2004: 11). Również i o tych terminach można powiedzieć, słowami cytowanej autorki, iż przekształciły się „,W prostą formułkę [...] powtarzaną jak zaklęcie, często bez głębszego zrozumienia, w podręcznikach i kursach językoznawstwa ogólnego" (ibid.). Przy czym istota tego rozróżnienia, podobnie jak teza o znakowym charakterze języka, nie jest wcale oczywista: zwracają na to uwagę między innymi Hjelmslev (1979) i Coşeriu (1967, 1981).

Niezależnie od tego, jaki sens, a zwłaszcza jaki zakres, zostanie nadany przywołanym tu pojęciom (i pojęciom pokrewnym, takim jak np. tekst 
w znaczeniu zaproponowanym przez Zawadowskiego (1966)), samo rozróżnienie spowodowało, że perspektywa nadawcy, czyli perspektywa kodowania, została w językoznawstwie strukturalnym w zasadzie relegowana do sfery parole. W szeroko rozumianym językoznawstwie poststrukturalistycznym kwestia miejsca tej perspektywy w opisie języka i w teorii języka nie jest już tak oczywista, choć, co pokażemy dalej, w większości przyjmowanych obecnie koncepcji opisu języka nie jest ona nigdy reprezentowana w postaci czystej. Perspektywa ta leży jednak u podstaw tzw. gramatyki kodowania (ang. Encoding Grammar), zaproponowanej przeze mnie w pracy (Linde-Usiekniewicz 2012a). Jednym z istotnych elementów tego podejścia jest rozróżnienie między tzw. reprezentacjami a tzw. strukturami (więcej na temat samego modelu powiemy niżej). W proponowanym tam ujęciu reprezentacje należą do parole, a struktury - do systemu języka, czyli langue (Linde-Usiekniewicz 2012a: 35, 65-74, 74-82; 2012b: 276). W niniejszym artykule pokażemy, że teza ta jest nadmiernym uproszczeniem, jako że analogia ta jest jedynie częściowa.

Nasz wywód przedstawimy następująco. W pierwszej sekcji pokażemy, na ile można doszukiwać się analogii między parole a właśnie kodowaniem rozumianym jako produkowanie wypowiedzeń; w sekcji drugiej zajmiemy się (nie)obecnością perspektywy kodowania we współczesnych modelach języka. W sekcji trzeciej przedstawimy szkicowo wspomnianą już gramatykę kodowania. W sekcji czwartej przyjrzymy się dokładniej odpowiedniości między konstruktami tego podejścia a langue i parole rozumianymi mniej schematycznie.

\section{2. „Langue", „langage" i ,parole" a perspektywa kodowania}

De Saussure'owskie rozróżnienie langue : parole jest przyjmowane jako fundamentalne (por. Polański 2002: 11); nie bez powodu Hjelmslev (1979) nawiązał do niego w tytule swojego artykułu, a Coşeriu (1967) uczynił przedmiotem kilkudziesięciostronicowych rozważań. Mniejszą uwagę poświęca się trzeciemu pojęciu, a mianowicie langage. Jedną z przyczyn jest być może fakt, że wiele języków, na które Kurs przetłumaczono, nie ma odpowiednich trzech wyraźnie różnych terminów. W polskim przekładzie tłumaczka konsekwentnie tłumaczy langue jako język; langage jako mowa, a parole jako mówienie; niemniej rozróżnienie mowa : mówienie umyka przy nie dość 
uważnej lekturze. W Szkicach (Saussure 2004), stanowiących polski przekład Écrits de linguistique générale (Saussure 2002a), autorka przekładu najwyraźniej zastąpiła termin parole odpowiednikiem wypowiedź - świadczy o tym odpowiednie odesłanie (Saussure 2004: 316). Dodatkową komplikacje stanowi fakt, że w Szkicach pojawia się - w zasadzie nieobecne w Kursie pojęcie dyskursu. Wydaje się, że termin mowa zarezerwowano w Szkicach dla langage (por. Saussure 2004: 144-145), ale wyłaniający się ze Szkiców jej charakter (Saussure 2004: 202, 203; 207; 215) wskazuje na daleko silniejsze związki między langue i langage, niż to sugeruje polska para język : mowa. Niemniej, w Szkicach (Saussure 2004: 276) odnajdujemy również wprost pokazane relacje między langage, langue i parole, analogiczne do obecnych w Kursie (Saussure 2002b: 38-43). W Szkicach zauważamy też - nieobecne najwyraźniej w Kursie - pojęcie dyskursu (zwraca na to uwagę Danielewiczowa 2004: 22), ale za cenę zwiększenia terminologicznej niejednoznaczności: autorka przedmowy pisze bowiem o zamiarze stworzenia „gramatyki mowy (dyskursu)". Czy gramatyka dyskursu miałaby być tym samym, co „językoznawstwo mówienia” (Saussure 2002b: 47), w stosunku do którego z przywołanego tekstu Kursu przebija pewna rezerwa? ${ }^{1}$

Kurs wydaje się sugerować, iż język (langue) jest częścią langage:2

Lecz cóż to jest język? Dla nas nie utożsamia się on z mową [langage]; jest to jedynie jej określona część, co prawda istotna. Jest to równocześnie społeczny wytwór zdolności mowy [faculté du langage] oraz ogół niezbędnych konwencji przyjętych przez grupę społeczną, aby jednostki mogły z tej zdolności korzystać (Saussure 2002b: 36).

Samo korzystanie ze zdolności mowy, podobnie jak i jego przejawy, nie mają - zdaniem de Saussure'a - charakteru społecznego, definiującego langue (pomijamy tu fizyczną, fonacyjną stronę zjawiska):

${ }^{1}$ Nie wiadomo, czy jest to interwencja redaktorów Kursu (de Saussure 2004: 25), czy - jak uważa Hjelmslev (1979: 9) - efekt tego, w jakim momencie rozwoju językoznawstwa wygłaszane były wykłady, które stały się podstawą Kursu.

2 Szczegółową propozycję interpretacji terminu langage, znacznie bogatszą niż tu przywołana i w większym stopniu opartą na tekście Szkiców proponuje Danielewiczowa (2013). 
Część psychiczna również w całości nie wchodzi w grę: strona wykonawcza pozostaje poza nawiasem, gdyż wykonanie nie jest nigdy dziełem zbiorowości: jest ono zawsze indywidualne i pozostaje pod władzą jednostki; określimy ją nazwą mówienia (parole) (Saussure 2002b: 40).

Syntetycznie relacje między langue, langage i parole oddaje następujący cytat z notatek Riedlingera:

Zatem język (langue) jest zbiorem niezbędnych konwencji, przyjętych przez społeczność po to, ażeby umożliwić posługiwanie się zdolnością mowy przez jednostki [...] Zdolność mowy (faculté du langage) jest czymś różnym od języka, ale czymś, co się bez języka nie może zrealizować [...] Przez mówienie (parole) rozumie się akt jednostki realizującej swoją zdolność mowy za pomocą konwencji społecznej, jaką jest język [...] W mówieniu zawiera się pojęcie realizacji tego, na co zezwala konwencja społeczna (Saussure 2002b: 40, przyp. 10)

Wydaje się, że korzystanie ze zdolności mowy, którego warunkiem jest istnienie języka, obejmuje zarówno wytwarzanie wypowiedzi, jak i jej rozumienie. Świadczy o tym między innymi cytat: „Gdy słyszymy jakiś nieznany nam język, chwytamy wprawdzie dźwięki, lecz ponieważ go nie rozumiemy, pozostajemy poza obrębem faktu społecznego.” (Saussure 2002b: 40). Natomiast parole wydaje się być odpowiednikiem kodowania, czyli wytwarzania wypowiedzi: opisywana jest bowiem z perspektywy nadawcy, zarówno w Kursie:

Język nie jest funkcją mówiącego, jest on wytworem, który jednostka biernie rejestruje; nie zakłada nigdy uprzedniego przemyślenia, a refleksja występuje dopiero przy czynności klasyfikowania [...]

Mówienie natomiast jest indywidualnym aktem woli i inteligencji, w którym należy wyróżnić: a) kombinacje, za pomocą których mówiący posługuje się kodem językowym w celu wyrażenia własnej myśli; b) mechanizm psychologiczny pozwalający mu uzewnętrznić te kombinacje (Saussure 2002b: 41).

jak i w Szkicach:

Rytuał, msza, nie dadzą się porównać ze zdaniem, ponieważ stanowią tylko powtórzenie pewnego ciagu czynności. Wytworzenie zdania jest porównywalne z aktywnością kompozytora utworu muzycznego (nie zaś z aktywnością wykonawcy tego utworu) (Saussure 2004: 102). 
Co ciekawe, perspektywa dekodowania jest dla de Saussure'a obowiązująca przy podstawowych procedurach poprawnej identyfikacji jednostek języka (unités concretes):

Aby [...] upewnić się, że istotnie mamy do czynienia z jednostką, trzeba by przy porównaniu całego szeregu zdań, w których występuje ta jednostka, można było w każdym przypadku wydzielić ją z reszty kontekstu, stwierdzając, że rozgraniczenie to jest uzasadnione znaczeniem (Saussure 2002b: 127).

\section{Perspektywa kodowania we współczesnym językoznawstwie}

Jak już wspomniano wyżej, perspektywa kodowania jest w poststrukturalistycznych opisach języka słabo obecna ${ }^{3}$. Co prawda pierwsze interpretacje modelu generatywnego widziały w nim model procesu kodowania. Tak np. Hymes (2001: 56) wskazuje na podobieństwo między wczesnymi modelami generatywnymi a Humboldtowskim rozumieniem języka jako procesu (Humboldt 2002: 395, za Drzazgowska 2011: 60). Niemniej trudno uznać, że model gramatyki przedstawiony w programie minimalistycznym (Chomsky 1995) jest faktycznie modelem produkcji zdań (Linde-Usiekniewicz 2012a: 16-17). Podobnie modele funkcjonalne nie są do końca modelami produkcji wypowiedzi. Odpowiednie zastrzeżenia można znaleźć w oryginalnych pracach, np. w Hengeveld, Mackenzie (2008: 2) dla funkcjonalnej gramatyki dyskursu (FDG - Functional Discourse Grammar), w Lopatková, Plátek, Sgall (2007: 7) dla opisu funkcjonalno-generatywnego (FGD - Functional Generative Description). W innych pracach wynika to z samej natury opisywanego modelu - tak jest np. dla gramatyki leksykalno-funkcjonalnej ( $L e$ xical-Functional Grammar, por. Asudeh, Toivonen 2009), czy dla gramatyki konstrukcji (Goldberg 2006).

Nieco bardziej skomplikowana jest sytuacja perspektywy kodowania w modelu ,sens $\Leftrightarrow$ tekst”. Tak na przykład z jednej strony Mielczuk (Mel'čuk 1988: 46) podkreśla, że stworzony przez niego model przyporządkowywania

3 Podobnie zresztą, jak w językoznawstwie strukturalistycznym. Na przykład Hjelmslev w swojej propozycji zdefiniowania langue (w odróżnieniu od parole), mówiąc o langue rozumianym jako uzus (1979: 11) interpretuje uzus jako zdefiniowany jego przejawami, czyli obserwowalnymi tekstami. Wyraźne przeciwstawienie perspektywy kodowania i dekodowania oraz uznanie obu za równocenne odnajdujemy co prawda u Jakobsona (1971), ale tylko w odniesieniu do fonologii. 
kolejnych reprezentacji jest dwukierunkowy, ale uważa, że jawna perspektywa nadawcy jest dla językoznawstwa korzystniejsza. Niemniej, nie wszystkie rozwiązania szczegółowe pojawiające się w późniejszych pracach dopuszczają interpretację zgodną z perspektywą kodowania. Tak na przykład ustalenie rang aktantów głębinowoskładniowych odbywa się na podstawie ich związków z jednej strony $\mathrm{z}$ aktantami powierzchniowoskładniowymi (takimi jak podmiot, dopełnienie bliższe, dopełnienia dalsze itd.), z drugiej zaś z ich odpowiednikami w reprezentacji semantycznej (odpowiednimi aktantami semantycznymi) (Mel'čuk 2004: 254). Rozwiązanie takie jest nie do pogodzenia z jednorodnie przyjmowaną perspektywą kodowania, gdyż przy przekształcaniu reprezentacji semantycznej w głębinowoskładniową nadawca musiałby antycypować mającą dopiero powstać reprezentację powierzchniowoskładniową (Linde-Usiekniewicz 2012a: 150-151).

\section{Gramatyka kodowania}

Jednym z podstawowych rozróżnień zaproponowanych w gramatyce kodowania jest odróżnienie struktury i reprezentacji (Linde-Usiekniewicz 2012a: 35-37; 65-84; 141-148; Linde-Usiekniewicz 2012b: 273-276). Termin struktura odnosi się do systemu języka. Odpowiednio struktura semantyczna języka to zestaw konfiguracji znaczeń, dla których dany język posiada środki wyrazu, leksykalne, składniowe lub morfologiczne. Leksykalne elementy struktury semantycznej to leksemy wraz z własnościami składniowymi (Linde-Usiekniewicz 2012a: 65-74). Składniowe elementy struktury semantycznej języka to między innymi różnego typu inwersje, np. inwersja czasownika posiłkowego w języku angielskim o funkcji negacji (For no money she would dance naked. 'Za darmo zatańczy nago.' : For no money would she dance naked. 'Za żadne pieniądze nie zatańczy nago.'), inwersja liczebnika i rzeczownika w języku rosyjskim (Ivan pročital dvadcat' knig. 'Jan przeczytał dwadzieścia książek. : Ivan pročital knig dvadcat'. 'Jan przeczytał ze dwadzieścia książek), inwersja przymiotnika w językach romańskich (église ancienne 'stary kościół' : ancienne église 'dawny kościół' (Linde-Usiekniewicz 2012a: 78-80 i cytowana tam odnośna literatura) oraz składniowe wykładniki struktury tematyczno-rematycznej, takie jak zdania rozszczepione różnego typu i romańskie przeniesienie dopełnień do pozycji inicjalnej z reduplikacją lub bez niej, tak jak w hiszpańskich zdaniach Las manzanas, las 
compró Pedro, 'Jabłka to kupił Piotr' : Las manzanas compró Pedro [y no peras] 'To jabłka Piotr kupił [a nie gruszki]' (Linde-Usiekniewicz 2012a: 131 i cytowana tam odnośna literatura). Struktura składniowa języka to zestaw dostępnych w nim konstrukcji, np. możliwości diatezy gramatycznej, możliwości elipsy poszczególnych członów zdania itd. Morfologiczne środki kodowania znaczenia to na przykład genetivus partitivus w języku polskim (Linde-Usiekniewicz 2012a: 45).

Termin reprezentacja odnosi się do wypowiedzenia lub zdania. Wyróżnia się reprezentację semantyczną zdania (Linde-Usiekniewicz 2012a: 61-65; Linde-Usiekniewicz 2012b: 273-276), jego reprezentację głębinowoskładniową (Linde-Usiekniewicz 2012a: 141-148) i powierzchniowoskładniową (Linde-Usiekniewicz 2012a: 42-44; 143-144; 158-167)4. Operacja kodowania jest zatem przedstawiona w modelu jako przekształcanie jednej reprezentacji w drugą zgodnie ze strukturą języka.

Punktem wyjścia jest reprezentacja semantyczna wypowiedzenia, czyli te elementy znaczenia, które nadawca chce zakodować za pomocą dostępnych środków językowych - są to elementy, które potencjalny nadawca może odkodować z wypowiedzi, w odróżnieniu od wywnioskowania ${ }^{5}$. Tak na przykład reprezentacja semantyczna angielskiego zdania I called my lawyer. nie zawiera informacji ani o płci mówiącego, ani o płci nadawcy, w przeciwieństwie do możliwych polskich odpowiedników tego zdania Zadzwonitem/tam do mojego prawnika/mojej prawniczki. (Linde-Usiekniewicz 2012a: 37). Nie postuluje się jednak prostego związku reprezentacji semantycznej z powierzchniową reprezentacją (fonetyczną, ortograficzną, itd.), gdyż poszczególne elementy znaczenia mogą być kodowane zarówno środkami leksykalnymi (dobór odpowiedniego leksemu: prawnik//prawniczka), jak i składniowymi (por. przykłady różnych linearyzacji powyżej; reduplikacja dopełnienia w pierwszym hiszpańskim przykładzie dotyczącym kupowania jabłek i jej brak w drugim) i morfologicznymi (np. w postaci uzgodnień w cytowanym wyżej przykładzie czy w postaci powierzchniowomorfologicznego dopełniacza w polskich konstrukcjach partytywnych). Model ma zatem charakter modularny, a poszczególne moduły dysponują charakterystycznym dla siebie zestawem środków kodowania. Co więcej,

\footnotetext{
4 Wszystkie te terminy zilustrujemy przykładami w dalszej części wywodu.

5 Rozróżnienie to zaczerpnięte jest z teorii relewancji Sperbera i Wilson (1986).
} 
przyjmuje się, iż elementy znaczenia, dla których głębszy moduł nie ma odpowiednich środków, „przenikają” niezakodowane do modułu bardziej powierzchniowego, gdzie zostają zakodowane (Linde-Usiekniewicz 2012a: 40:45).Tak na przykład w podanych wyżej hiszpańskich przykładach dotyczących kupowania jabłek reprezentacja semantyczna pierwszego z nich zawiera informację o tematycznym charakterze elementu 'jabłka', natomiast drugiego o jego rematycznym charakterze ${ }^{6}$. Głębinowa reprezentacja składniowa dla obu zdań jest taka sama, gdyż opisuje wyłącznie zależności składniowe między predykatem 'kupić' a jego dwoma aktantami; tematyczny czy rematyczny charakter drugiego aktanta pozostaje jego własnością semantyczną, nieodzwierciedloną różnicami w kształcie głębokiej reprezentacji składniowej. Różnicę między tematycznym a rematycznym charakterem członu 'jabłka' koduje dopiero powierzchniowa reprezentacja składniowa: wspomniane wyżej przesunięcie dopełnienia do pozycji inicjalnej z reduplikacją w wypadku dopełnienia tematyzowanego i bez reduplikacji w wypadku dopełnienia rematyzowanego (Linde-Usiekniewicz, w druku). Reprezentacja semantyczna i obie reprezentacje składniowe mają charakter abstrakcyjny: bilateralne jednostki są w nich reprezentowane w oderwaniu od ich faktycznych signifiants. Końcowy etap kodowania polega na ostatecznej linearyzacji jednostek i przypisaniu im kształtu morfonologicznego oraz przypisaniu cech prozodycznych odpowiednim ciagom. Wynikiem jest reprezentacja powierzchniowa, ostateczny kształt zdania lub wypowiedzenia, możliwy do faktycznego zrealizowania w subkodzie pisanym lub mówionym języka. Działanie gramatyki kodowania ilustruje schemat przedstawiony na rycinie, zaczerpnięty z Linde-Usiekniewicz (2012a: 48).

${ }^{6}$ Referowana tu koncepcja zawiera także propozycję definicji struktury tematyczno-rematycznej w perspektywie kodowania. Brak miejsca nie pozwala na jej dokładniejsze omówienie. 


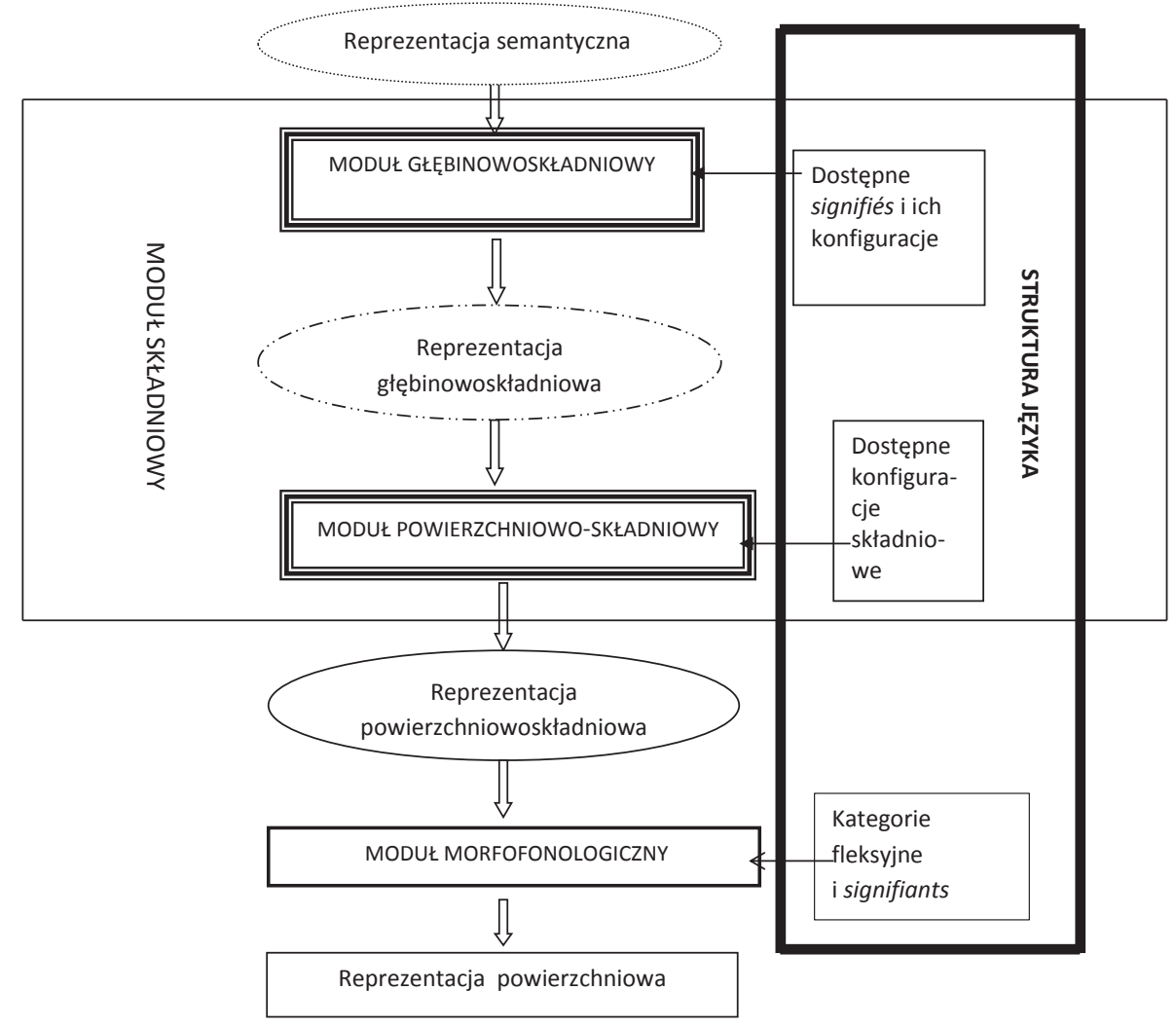

Ryc. Architektura gramatyki kodowania

\section{5. „Struktury" i „reprezentacje" a „langue" i ,parole"}

Jak już wspomniano, w pracy przedstawiającej gramatykę kodowania wielokrotnie zwracałam uwagę na podobieństwo zaproponowanego przez siebie rozróżnienia struktur i reprezentacji do rozróżnienia między langue i parole: struktury są odpowiednikami langue, a reprezentacje należeć miałyby do parole. Pod pewnymi względami analogia ta pozostaje właściwa. Struktura semantyczna danego języka nie podlega kontroli mówiącego: dany język naturalny po prostu albo dysponuje pewnymi środkami kodowania pewnych sensów, albo nie. Zestaw ten jest dostępny użytkownikom języka, niezależnie od tego, czy w danym momencie uczestniczą w komunikacji, czy 
nie. Tym samym można uznać, że odnosi się do niego poniższe twierdzenie de Saussure'a na temat langue:

Jest to skarb złożony dzięki praktyce mówienia w osobach należących do tej samej społeczności, przy czym system gramatyczny istnieje potencjalnie w każdym mózgu lub raczej w mózgach ogółu jednostek: w żadnej z nich nie jest jednak kompletny: w pełni istnieje tylko w zbiorowości” (Saussure 2002a: 40-41).

Odnotujmy jednak, że w przytoczonych przez polskiego wydawcę Kursu notatkach innych słuchaczy nie wspomina się - co ciekawe - o systemie gramatycznym. Nie jest też jasne, czy włożone przez redaktorów Kursu w usta de Saussure’a wyrażenie „system gramatyczny” miałoby odnosić się wyłącznie do morfologii, czy również do składni. Pamiętajmy bowiem, iż koncepcja języka jako alfabetu symboli i gramatyki jest późniejsza i wywodzi się z językoznawstwa generatywnego.

Przywołany ostatnio cytat jest istotny dla naszych rozważań również z innych powodów. Otóż pojawia się w nim teza, iż langue istnieje kompletnie wyłącznie w zbiorowości. Z jednej strony pokazuje to, jak fundamentalna jest różnica między de Saussure'em a językoznawstwem generatywnym. Tym samym analogia między langue a generatywną kompetencja, wspomniana przez cytowanego już Hymesa (2001: 56) jest niepełna: kompetencja, nawet idealna, jest zawsze kompetencją jednostkową. W tym zresztą kierunku idzie też generatywne odróżnienie między językiem wewnętrznym (I-language), stanowiącym dla językoznawstwa generatywnego podstawowy, jeżeli nie jedyny, obiekt badań, a językiem zewnętrznym (E-language), uznanym przez Chomsky’ego (1986: 25) za epifenomen. Z drugiej strony zaś, jeżeliby przyjać, jak sugerowałam w omawianej tu pracy (Linde-Usiekniewicz 2012a), iż struktura języka jest tożsama z langue i że dostęp do niej warunkuje możliwość zakodowania odpowiedniej reprezentacji semantycznej, trzeba by zarazem przyjąć, że każdemu użytkownikowi języka dostępna jest całość owej struktury. Jest to zbyt daleko idąca idealizacja.

Kolejne zagadnienie, któremu warto się przyjrzeć, to postulowana analogia pomiędzy strukturą składniową języka a langue. $\mathrm{Z}$ jednej strony bowiem ,[w]łaściwością mówienia jest swoboda w tworzeniu połączeń” (Saussure 2002b: 149), co by sugerowało, że składnia w całości znajduje się poza obrębem langue, ale ,[t] rzeba jednak przyznać, że w dziedzinie syntagmy nie 
ma wyraźnie zarysowanej granicy między faktem języka, noszącym znamię zbiorowego użycia, a faktem mówienia, zależnym od indywidualnej swobody" (Saussure 2002b: 150). Niemniej w tym samym miejscu czytamy, iż:

Do języka, a nie do mówienia należy zaliczyć wszelkiego typu syntagmy zbudowane na podstawie form regularnych. Istotnie, ponieważ w języku nie ma nic abstrakcyjnego, typy te istnieją tylko o tyle, o ile język zarejestrował dostateczną liczbę ich egzemplarzy. [...] Dokładnie tak samo przedstawia się sprawa ze zdaniami i grupami wyrazów utworzonymi według wzorów regularnych; połączenia takie jak la terre tourne, que vous dit-il? itd. odpowiadają typom ogólnym, które z kolei znajdują oparcie w języku pod postacią konkretnych przypomnień (Saussure 2002b: 149-150).

W podobnym duchu - jako uznanie składni za należącej do języka można też interpretować rozdział o Roli bytów abstrakcyjnych $w$ gramatyce (Saussure 2002b: 165). Jeżeli jednak wszelkie „by ty abstrakcyjne opierają się zawsze, w ostatecznej analizie, na bytach k o k retnych" (Saussure 2002b: 165, podkreślenie oryginalne), do langue można próbować zaliczyć tylko te elementy składniowe, które znajdują odzwierciedlenie w zjawiskach powierzchniowych, czyli elementy składni powierzchniowej. W świetle tego, umieszczenie struktury składniowej (w rozumieniu gramatyki kodowania) jako elementu modułu powierzchniowoskładniowego, a nie głębinowoskładniowego (por. rysunek) wydaje się zgodne z tezami Kursu. Niemniej w Szkicach czytamy:

Mianem syntagmy określamy wypowiedź spełnioną

- lub kombinację elementów zawartych we fragmencie rzeczywistej wypowiedzi

- lub porządek, w jakim te elementy przez swoją uprzedniość i następstwo są dane.

W opozycji do paralelności lub wypowiedzi potencjalnej, lub zbioru elementów ujmowanych i wiązanych przez umysł, albo też porządku, w jakim pewien element istnieje abstrakcyjnie wśród innych możliwych elementów (Saussure 2004: 73, podkreślenie oryginalne).

Oznaczać to może, że możliwa jest jakaś składnia potencjalna, być może tożsama z owym „systemem gramatycznym” (zob. wyżej), którego natury nie byliśmy pewni. 
Czy jednak poszczególne reprezentacje można uznać analogicznie za odpowiedniki parole? Tu sprawa nie jest taka prosta. Niewątpliwie sam proces kodowania to właśnie parole. Co więcej, jak już wspomniano, powierzchniowe reprezentacje składniowe stanowią właśnie przywołane wyżej „syntagmy spełnione” i/lub „oparcie w języku” dla typów ogólnych. Tym samym należą, przynajmniej w jakimś sensie, także do langue, oczywiście w takim sensie, w jakim parole to „kombinacje, za pomocą których mówiący posługuje się kodem językowym w celu wyrażenia własnej myśli” (Saussure 2002b: 40). Inaczej przedstawia się sprawa reprezentacji semantycznej. W przyjętym tu rozumieniu jest niezależna od konkretnego języka (Linde-Usiekniewicz 2012b: 276), a więc od langue. Jej ,ujęzykowienie” zachodzi dopiero w module głębinowoskładniowym. To tam właśnie zachodzi proces opisany jako:

Charakterystyczna rola języka w stosunku do myśli polega nie na stworzeniu materialnego, dźwiękowego środka dla wyrażenia pojęć, lecz na pośrednictwie między myślą a dźwiękiem w takich warunkach, że ich łączenie prowadzi nieuchronnie do wzajemnych rozgraniczeń jednostek. Myśl, z natury chaotyczna, przy rozczłonkowaniu musi się sprecyzować (Saussure 2002b: 136).

Oznacza to, że o ile uzasadniona jest analogia między langue a strukturami (semantyczną i składniową) w sensie, jaki nadałam owym pojęciom, to analogia pomiędzy reprezentacjami a parole jest chybiona. Jedyna reprezentacja w jakikolwiek sposób podobna do parole to reprezentacja powierzchniowa. Analogiem parole natomiast jest w jakimś sensie sama idea gramatyki kodowania. Kwestia wyboru nadawcy odnośnie do użytych w wypowiedzi jednostek (Linde-Usiekniewicz 2012a: 25, 35-40) może być uznana za de Saussure'owski ,indywidualny akt woli i inteligencji”. Nie wydaje się jednak, żeby mogła przypominać planowane przez de Saussure’a ,językoznawstwo mówienia" (Saussure 2002b: 47), ze względu na swój transformacyjny charakter.

\section{Zakończenie}

Mimo pociągającej na pierwszy rzut oka analogii między perspektywą kodowania w opisie języka, niezależnie od tego, czy jest ona jedynie sposobem prezentacji modelu, czy też podstawowym wyznacznikiem jego budowy, a de Saussure'owską parole nie wydaje się, by podobieństwo to było na 
tyle bliskie, by można było utożsamiać kodowanie i parole. Dokładniejsze przyjrzenie się tym pojęciom pokazuje, że ich pozorna bliskość sprowadza się do tego, że każde z nich opisywane jest jako przeciwstawne wobec czegoś bardziej abstrakcyjnego, co z jednej strony umożliwia, a z drugiej strony w jakimś sensie ogranicza faktyczną działalność mowną.

W szczególności nie ma uzasadnienia dla twierdzenia, że reprezentacje zdań, opisywane przeze mnie jako element gramatyki kodowania, stanowią elementy parole. Reprezentacja semantyczna zdania, tak jak ją rozumiem, w ujęciu de Saussure'owskim musiałaby znaleźć się poza językiem, natomiast reprezentacja głębinowoskładniowa i powierzchniowoskładniowa są jedynie konstruktami teoretycznymi, dla których w koncepcji de Saussure'a chyba nie ma miejsca, nawet w planowanym przez niego ,językoznawstwie mówienia".

\section{Bibliografia}

Asudeh A., Toivonen I., 2009, Lexical-Functional Grammar, w: B. Heine, H. Narrog (eds.), The Oxford Handbook of Linguistic Analysis, Oxford: Oxford University Press, s. 425-458.

Chomsky N., 1986, Knowledge of Language: Its Nature, Origins, and Use, Nowy Jork: Praeger.

Cномsкy N., 1995, The Minimalist Program, Cambridge, MA: The MIT Press.

Coşeriu E., 1967, Sistema, norma y habla, w: idem, Teoría del lenguaje y lingüistica general, Madryt: Gredos, s. 11-113.

Coşeriu E., 1981, Lecciones de lingüistica general, Madryt: Gredos.

Danielewiczowa M., 2004, Przedmowa do wydania polskiego. Ferdynand de Saussure - siła paradoksu, w: F. de Saussure, Szkice z językoznawstwa ogólnego, Warszawa: Wydawnictwo Akademickie Dialog, s. 11-24.

Danielewiczowa M., 2013, Langage - kłopotliwy element Saussure'owskiej triady, Przeglad Humanistyczny 5, s. 5-15.

DrzazGowska E., 2011, Humboldt: przełamanie arystotelesowskiego modelu relacji oznaczania, Lingua ac Communitas 21, s. 53-78.

Goldberg A., 2006, Construction at Work. The Nature of Generalizations in Language, Oxford: Oxford University Press.

Hengeveld K., Mackenzie J. L., 2008, Functional Discourse Grammar. A typologically-based theory of language structure, Oxford: Oxford University Press. 
HJelmslev L., 1979, „Langue” i „parole”, w: H. Kurkowska, A. Weinsberg (red.), Językoznawstwo strukturalne, Warszawa: Państwowe Wydawnictwo Naukowe, s. 9-17.

Humboldt W., 2002, O myśli i mowie - wybór pism z teorii poznania, filozofii dziejów i filozofii języka, tłum. E. M. Kowalska, Warszawa: Wydawnictwo Naukowe PWN.

Hymes D., 2001, On communicative competence, w: A. Duranti (red.), Linguistic anthropology, Oxford: Blackwell, s. 53-73.

JAKOBSON R., 1971, Zeichen und System der Sprache. Discussionsbeitrag, Selected Writings II, Berlin: Walter de Gruyter, s. 272-279.

Linde-Usiekniewicz J., 2012a, From Conflict Through Compromise to Collaboration: Semantics, Syntax and Information Structure in Natural Languages: Warszawa, Nakładem Wydziału Polonistyki.

Linde-UsieKniewicz J., 2012b, Czy istnieje struktura semantyczna języka?, w: A. Mikołajczuk, K. Waszakowa (red.), Odkrywanie znaczeń w języku, Warszawa: Wydawnictwa UW, s. 263-279.

Linde-UsieKNIEWICZ J., w druku, El objeto directo e indirecto dislocados y pleonásticos en la sintaxis de dependencia.

Lopatková M., Plátek M., Sgall P., 2007, Towards a Formal Model for Functional Generative Description. Analysis by Reduction and Restarting Automata, The Prague Bulletin of Mathematical Linguistics 87 (June 2007), s. 7-26.

MeL'ČUK I. A., 1988, Dependency Syntax: Theory and Practice, Albany: SUNY Press.

MeL'Čuk I. A., 2004, Actants in Syntax, Linguistics 42: 2, s. 247-291.

Polański K., 2002, Wprowadzenie, w: F. de Saussure, Kurs językoznawstwa ogólnego, Warszawa: Wydawnictwo Naukowe PWN, s. 5-22.

SAussure F. DE, 2002a, Écrits de linguistique générale, Paryż: Gallimard.

SAUSSURE F. DE, 2002b, Kurs językoznawstwa ogólnego, Warszawa: Wydawnictwo Naukowe PWN.

SAussure F. DE, 2004, Szkice z językoznawstwa ogólnego, Warszawa: Wydawnictwo Akademickie Dialog.

Sperber D., Wilson D., 1986, Relevance. Communication and Cognition, Oxford: Oxford University Press.

Zawadowski L., 1966, Lingwistyczna teoria języka, Warszawa: Państwowe Wydawnictwo Naukowe. 
Between Langue and Parole:

Language in the Perspective of Coding

(summary)

The paper discusses a claim, presented by Linde-Usiekniewicz in her book From Conflict Through Compromise to Collaboration: Semantics, Syntax and Information Structure in Natural Languages, about similarities between some elements of her framework and de Saussure's langue vs. parole distinction. The framework discussed, called Encoding Grammar, distinguishes language structures that comprise lexical units and their configurations available within a given language and representations of sentences and utterances that appear at different stages of encoding. The paper argues that while there is some valid correspondence between the notion of structure and that of langue, the analogy does not hold for representations and parole. 
